\title{
Pengaruh Social Media dan Event Marketing terhadap Minat Beli di Pyukanau Official
}

\author{
Nisya Firdailla \\ Politeknik Piksi Ganesha \\ Jl.Gatot Subroto No.301, Maleer, Kec.Batununggal, Kota Bandung \\ Jawa Barat, Indonesia 40274 \\ Hanni Haerani \\ Islamic Fashion Institute \\ Jl. Jendral Ahmad Yani No.390, Kebonwaru, Kec. Batununggal, Kota Bandung \\ Jawa Barat, Indonesia 40272
}

\begin{abstract}
Abstrak
Tujuan penelitian ini untuk mengetahui pengaruh dari Social Media serta Event Marketing terhadap Minat Beli produk fashion. Metode yang dipakai kuantitatif, korelasi mencari hubungan antara variabel. Pada penelitian ini populasinya adalah followers Instagram Pyukanau Official yang berjumlah 544 dengan menggunakan rumus Slovin diperlukan 100 orang responden. Pengambilan sampel menggunakan teknik purposive probability sampling dengan menyebar angket melalui Google Form. Hasil dari pengujian menggunakan IBM SPSS Statistics version 26.0 adalah nilai $\mathrm{R} 0,867$ dan koefisien $\mathrm{R}^{2} 0,752$ atau $75,2 \%$. Social media berpengaruh terhadap minat beli dengan nilai thitung 4,697 > t tabel 1,984, event marketing berpengaruh terhadap minat beli dengan nilai t hitung 5,824 > t tabel 1,984, dan secara simultan antara sosial media (X1), event marketing (X2), terdapat pengaruh positif yang signifikan terhadap minat beli (Y) di Pyukanau Official dengan nilai Sig $0,000^{\mathrm{b}}(\mathrm{p}<0,05)$.

Kata kunci: sosial media, event marketing, minat beli
\end{abstract}

\section{PENDAHULUAN}

Kompetisi di dunia usaha merupakan tantangan yang mesti dialami pengusaha dalam menggadang brand produknya (Gunawan, 2016). Ini sangat dipengaruhi oleh kemajuan era teknologi dan pergantian selera konsumen dari offline ke online (Ishak \& Somadi, 2019). Keberhasilan pemasaran lewat social media, merupakan fakta semakin berartinya keberadaan social media yang menyebabkan konsumen lebih difasilitasi. Di Indonesia pemasaran lewat social media menampilkan pertumbuhan pesat sebab biayanya ekonomis, gampang, bisa mempersingkat waktu serta dapat diakses seluruh kalangan (Dahmiri, 2020). Social media yaitu teknologi baru yang membuat kita lebih efisien serta efektif dalam membentuk ikatan dengan pelanggan dan mempunyai kesempatan luas menemukan keuntungan untuk pelakon pemasaran (Neneng Nurmalasari \& Masitoh, 2020). Lewat social media menolong pelaku usaha dalam memikat konsumen lewat tarif yang sedikit serta dalam waktu kilat ditambah review yang mendukung (Indika \& Jovita, 2017). Karenanya banyak perusahaan bersaing menjalin korelasi kepada konsumennya melalui social media supaya mempengaruhi minat beli (Kuspriyono \& Nurelasari, 2018).

Selain social media, event marketing merupakan tipe promosi yang banyak digunakan sebagai media offline untuk bersaing memasarkan produknya. Perusahaan ataupun brand yang tergabung ke event akan menciptakan sebuah pengalaman, dan juga mempromosikan produk atau jasa kepada pelanggan (Ratnawati \& Hanifa, 2019). Pemasaran melalui event marketing juga merupakan strategi yang dipandang dapat menghadapi persaingan (Syafiq, 2017). Event marketing yang dilakukan perusahaan wajib mempunyai dampak serta membagikan kesan mendalam kepada tiap pelanggan, agar pelanggan dapat lama mengingat pengalaman yang mengasyikkan serta bakal loyal terhadap merek ataupun produk tersebut (Ningrum \& Nilowardono, 2016). Semakin banyaknya perusahaan atau brand yang bersaing lewat media offline khususnya event, dinilai penting dan berpengaruh dalam menarik minat beli pelanggan (Anugerah \& Hidayat, 2018). 
Minat beli ialah niatan pada diri individu untuk membeli produk atau jasa melalui pertimbangan sebelum proses pembelian (Bakti et al., 2020). Minat Beli juga merupakan proses antara penilaian alternatif serta keputusan pembelian. Sehabis konsumen melaksanakan penilaian, kemudian akan timbul hasrat buat membeli sesuatu produk barang ataupun jasa yang dijual (Sugianto Putri, 2016). Berdasarkan tabel 1 di bawah ini merupakan jumlah dan nilai persentase Subsektor Ekonomi Kreatif berdasarkan Bekraf Information System on Mobile Application (BISMA) di Jawa Barat. Industri fashion menunjuk angka 12,44\% yang berarti masih banyak pelaku usaha dibidang ini dibandingkan bidang industri lainnya, meskipun masih di bawah industri kuliner.

Tabel 1. Sebaran Pelaku Ekonomi Kreatif Jawa Barat

\begin{tabular}{lc}
\hline \multirow{2}{*}{\multicolumn{1}{c}{ Berdasarkan Subsektor }} & Pelaku EKARAF \\
\cline { 2 - 2 } & Persentase \\
\hline Kuliner & $31,89 \%$ \\
Kriya & $5,97 \%$ \\
Fesyen & $12,44 \%$ \\
Tv \& Radio & $0,63 \%$ \\
Penerbitan & $2,51 \%$ \\
Musik & $2,17 \%$ \\
Arsitektur & $0,51 \%$ \\
App \& Games & $3,49 \%$ \\
Periklanan & $0,99 \%$ \\
Fotografi & $1,84 \%$ \\
DKV & $5,05 \%$ \\
Desain Produk & $2,91 \%$ \\
Film, Animasi \& Video & $6,10 \%$ \\
Seni Rupa & $1,59 \%$ \\
Seni Pertunjukan & $1,18 \%$ \\
Desain interior & $1,25 \%$ \\
Subsektor lainnya & $\mathbf{1 9 , 4 8 \%}$ \\
\hline
\end{tabular}

Sumber: Update Data BISMA per 30 Juni 2019 (Munaf, 2019)

Kota Bandung menjadi kota yang dikenal dengan kota fashion (Irna \& Tafeni, 2020). Dilihat dari tabel 2 di bawah ini, industri fashion terutama pakaian di Kota Bandung mengalami kenaikan tiap tahun dari tahun 2016-2018. Industri pakaian menunjukkan jumlah industri tertinggi meskipun kenaikan persentase tiap tahunnya kecil dibanding industri fashion lainnya.

Tabel 2. Industri Fesyen Kota Bandung

Fokus:

Sosial dan

Budaya

Ruang lingkup: Humaniora Pendidikan, Manajemen, Sejarah, Ekonomi, Linguistik, Sastra, Agama, Politik, Sosiologi, Antropologi, dan lainnya.

\begin{tabular}{lccccc}
\hline $\begin{array}{c}\text { Jenis Industri } \\
\text { Fashion }\end{array}$ & $\mathbf{2 0 1 6}$ & $\begin{array}{c}\text { Persentase } \\
\text { Kenaikan }\end{array}$ & $\mathbf{2 0 1 7}$ & $\begin{array}{c}\text { Persentase } \\
\text { Kenaikan }\end{array}$ & $\mathbf{2 0 1 8}$ \\
\hline Aksesoris & 362 & $31,2 \%$ & 475 & $42,1 \%$ & 675 \\
Lifestyle & 263 & $50,1 \%$ & 395 & $21,5 \%$ & 480 \\
Pakaian & 675 & $15,1 \%$ & 795 & $14,2 \%$ & 927 \\
$\quad$ JUMLAH & 1300 & & 1665 & & 2082 \\
\hline
\end{tabular}

Persaingan bisnis bidang fashion utamanya bidang pakaian di Kota Bandung sangat kompetitif, banyak pesaing berlomba memasarkan brand lokalnya (Anugerah \& Hidayat, 2018). Menggunakan brand lokal jadi langkah strategis karena bisa untuk mempromosikan produk buatan Indonesia di pasar dalam negeri maupun luar negeri (Meitasari \& Setiawati, 2020). Brand lokal mesti diperhitungkan sebab bertambah lama merek lokal semakin diminati, dibuktikan dengan banyak produk baru berdatangan (Anggraeni et al., 2018). Setiap brand lokal perlu menanggapi perubahan mode demi menarik perhatian konsumen (Gunawan, 2016). Syarat brand lokal agar tetap hidup adalah membangun citra merek dengan cara menyuguhkan keunikan atau ciri khas sehingga mudah diingat (Pramesti, 2018).

Dikutip dalam diary blog Pyukanau Official: "PYUKANAU adalah merek streetwear sederhana yang berbasis di Bandung, Indonesia. PYUKANAU secara kreatif diambil dari nama lengkap yaitu Putri Nur Kharisma, yang berarti jiwa yang dipenuhi cahaya kegembiraan”. Dari 
hasil wawancara kepada owner Pyukanau Official, bahwa Pyukanau Official adalah brand fashion lokal yang diciptakan setelah dia lulus dari Islamic Fashion Institute (IFI) di Kota Bandung. Pyukanau Official pada 2019 pernah mengikuti sebuah Event Muslim Fashion Festival (MUFFEST), kemudian pada 2020 menjadi sponsor Ajang Apresiasi Duta Genre Jakarta Utara, dan terakhir pada pertengahan 2021 ini Pyukanau Official diundang untuk bergabung ke Event Philippine International Virtual Modest Fashion Show yang disiarkan langsung di Youtube Modest Fashion Designers Channel. Di bawah ini merupakan data penjualan dari Pyukanau Official seri mini collection awal 2021 adalah sebagai berikut:

Tabel 3. Data Penjualan Pyukanau Official (Survivor Mini Collection 2021)

\begin{tabular}{llccc}
\hline \multicolumn{1}{c}{ Nama Barang } & \multicolumn{1}{c}{ Jenis Barang } & $\begin{array}{c}\text { Harga } \\
\text { Satuan }\end{array}$ & $\begin{array}{c}\text { Barang } \\
\text { Keluar }\end{array}$ & Total \\
\hline Zero Kimono Cardigan & Outwear & Rp 399.000; & 8 & Rp 3.192.000; \\
Link Kimono Cardigan & Outwear & Rp 399.000; & 10 & Rp 3.990.000; \\
Positivity Kimono Cardigan & Outwear & Rp 350.000; & 10 & Rp 3.500.000; \\
Zero Mask & Face Mask (earloop) & Rp 40.000; & 10 & Rp 400.000; \\
Positivity Mask & Face Mask (earloop) & Rp 40.000; & 10 & Rp 400.000; \\
Link Mask & Face Mask (earloop) & Rp 40.000; & 10 & Rp 400.000; \\
Zero Mask & Face Mask (headloop) & Rp 40.000; & 10 & Rp 400.000; \\
Positivity Mask & Face Mask (headloop) & Rp 40.000; & 10 & Rp 400.000; \\
Link Mask & Face Mask (headloop) & Rp 40.000; & 10 & Rp 400.000; \\
& & & & Rp 13.082.000;
\end{tabular}

Hal yang menarik adalah produk dari Pyukanau ini termasuk ke dalam slow fashion. Slow fashion adalah tentang merancang, dan memproduksi fashion tidak berdasarkan waktu tetapi berdasarkan kualitas (Bellido-Pérez, 2019). Pyukanau Official merupakan Produk yang dirancang khusus dengan model yang unik dan limited edition. Menggunakan teknik printing sublime kain yang memberikan kesan mahal dan tidak pasaran karena memiliki ciri khas desain sendiri dengan warna colourfull dan bisa digunakan untuk unisex. Selain pakaian untuk sehari-hari, produk di Pyukanau juga biasanya diperagakan model di catwalk pada saat fashion show, di sewakan juga untuk berbagai acara misalnya; dipakai $m c$, dipakai menyanyi, dan pentas di panggung. Produk dari Pyukanau Official juga pernah berkolaborasi dan digunakan oleh beberapa selebriti, seperti Melly Goeslow, Soraya larasati, Nycta Gina dan masih banyak lainnya.

Pada penelitian terdahulu (Setiawati, 2015) bermaksud untuk memahami pengaruh social media terhadap minat beli pelanggan mahasiswa Manajemen Universitas Pasir Pangaraian. Hasilnya adalah social media berpengaruh pada minat beli pelanggan. Kemudian penelitian terdahulu yang kedua (Ratnawati \& Hanifa, 2019) bertujuan untuk memahami implementasi pelaksanaan event marketing berdasarkan minat beli mobil Daithasu. Hasilnya event marketing berpengaruh pada minat beli pelanggan. Berdasarkan fenomena yang telah dijabarkan diatas penelitian ini bertujuan untuk mengetahui apakah ada pengaruh antara social media dan event marketing terhadap minat beli di Pyukanau Official.

\section{METODE}

Metode pendekatan penelitian ini adalah kuantitatif. Disebut metode kuantitatif karena mengolah angka-angka yang kemudian di analisis datanya secara statistik (Sugiyono, 2013). Informasi dikumpulkan lewat alat pengumpul data Observasi, wawancara serta angket. Menyebar angket melalui Google Form model evaluasinya yaitu pernyataan yang di sebar luaskan berkaitan dengan variabel yang di teliti merujuk skala Likert 5 poin.

Populasi pada penelitian adalah followers Instagram Pyukanau Official yang berjumlah 544 dengan menggunakan rumus Slovin diperlukan 100 orang responden. Pengambilan sample memakai teknik purposive probability sampling, yaitu teknik pengumpulan data didasarkan pada penilaian yang pasti mengenai keseluruhan populasi.
Vol. 3, No. 2,

Oktober 2021,

hal. 171-179

2686-5009

Pengaruh

Social Media

dan Event

Marketing

terhadap

Minat Beli di

Pyukanau

Official

Nisya Firdailla

Hanni Haerani 
LITERATUS

adalah jurnal

yang

diterbitkan

oleh

Neolectura, diterbitkan dua

kali dalam satu tahun.

LITERATUS

adalah media publikasi ilmiah dalam bentuk makalah konseptual dan penelitian lapangan yang terkait dengan bidang kajian sosial dan budaya.

Diharapkan LITERATUS dapat menjadi media bagi akademisi dan peneliti untuk menerbitkan karya ilmiah mereka dan menjadi sumber referensi untuk pengembangan ilmu pengetahuan.

Fokus:

Sosial dan

Budaya

Ruang lingkup: Humaniora Pendidikan, Manajemen, Sejarah, Ekonomi, Linguistik Sastra, Agama, Politik, Sosiologi, Antropologi, dan lainnya.

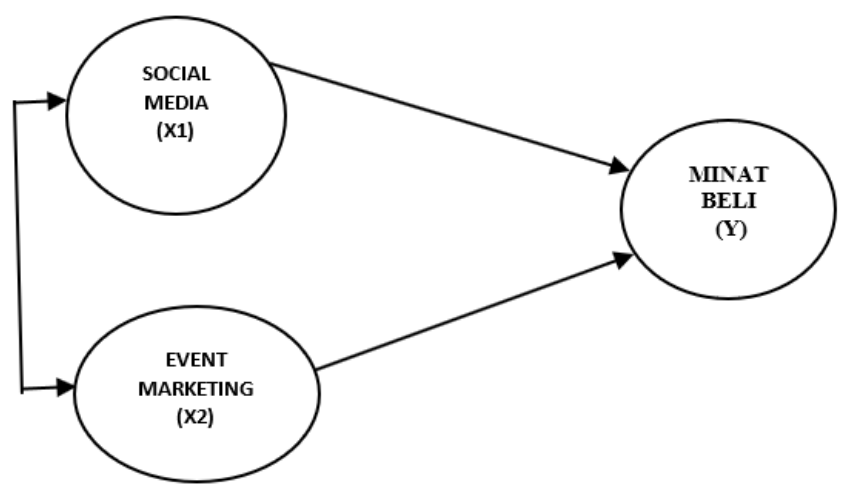

Gambar 1. Kerangka Pemikiran

Berdasarkan gambar 1 terdapat kerangka berpikir dari penelitian yaitu paradigma ganda dua variabel independen (bebas) $\mathrm{X} 1, \mathrm{X} 2$, dan satu variabel dependen (terikat) $\mathrm{Y}$.

\section{HASIL DAN PEMBAHASAN}

Hasil

Kuesioner angket disebar melalui Google Form kemudian memperoleh gambaran umum mengenai karakteristik responden. Berdasarkan tabel 4 di bawah, karakteristik yang menjadi responden dikelompokkan dengan: jenis kelamin, jenis pekerjaan, usia, dan Pendidikan. Yang mendominasi karakteristik responden adalah wanita $80 \%$, rata-rata usia 20-25 tahun $87 \%$, yang pendidikan terakhir SMA/SMK 76\% dan pekerjaannya karyawan $42 \%$.

\section{Tabel 4. Responden}

\begin{tabular}{|c|c|c|}
\hline Keterangan & Jumlah & Persentase \\
\hline $\begin{array}{l}\text { Jenis Kelamin: } \\
\text { Wanita }\end{array}$ & 80 & $80 \%$ \\
\hline Pria & 20 & $20 \%$ \\
\hline $\begin{array}{l}\text { Usia: } \\
20-25\end{array}$ & 87 & $87 \%$ \\
\hline $\begin{array}{l}25-30 \\
35-40\end{array}$ & $\begin{array}{c}12 \\
1\end{array}$ & $\begin{array}{c}12 \% \\
1 \%\end{array}$ \\
\hline $\begin{array}{l}\text { Pendidikan: } \\
\text { SMA/SMK }\end{array}$ & 76 & $76 \%$ \\
\hline $\begin{array}{l}\text { D3 } \\
\text { D4 } \\
\text { S1 }\end{array}$ & $\begin{array}{c}5 \\
2 \\
17\end{array}$ & $\begin{array}{c}5 \% \\
2 \% \\
17 \%\end{array}$ \\
\hline $\begin{array}{l}\text { Pekerjaan: } \\
\text { Pelajar \& Mahasiswa }\end{array}$ & 30 & $30 \%$ \\
\hline $\begin{array}{l}\text { Karyawan } \\
\text { Ibu Rumah Tangga }\end{array}$ & $\begin{array}{l}42 \\
12\end{array}$ & $\begin{array}{l}42 \% \\
12 \%\end{array}$ \\
\hline $\begin{array}{l}\text { Enterpreneur } \\
\text { Freelance }\end{array}$ & $\begin{array}{c}10 \\
2\end{array}$ & $\begin{array}{l}10 \% \\
25 \%\end{array}$ \\
\hline $\begin{array}{l}\text { Guru } \\
\text { Perawat }\end{array}$ & $\begin{array}{l}1 \\
1\end{array}$ & $\begin{array}{l}1 \% \\
1 \%\end{array}$ \\
\hline $\begin{array}{l}\text { Barista } \\
\text { Influencer }\end{array}$ & $\begin{array}{c}1 \\
1 \\
\mathbf{1 0 0}\end{array}$ & $\begin{array}{c}1 \% \\
1 \% \\
\mathbf{1 0 0 \%}\end{array}$ \\
\hline
\end{tabular}

Setelah penyebaran kuesioner ke 100 responden, kemudian dilakukan perhitungan menggunakan IBM SPSS Statistics Version 26.0. Uji validitas yaitu menguji kevalidan pernyataan kuesioner dengan perbandingan $\mathrm{r}$ hitung dan $\mathrm{r}$ tabel mengaplikasikan tingkat kesalahan $5 \%$. 
Tingkat kesalahan ini $r$ tabel disignifikasikan 0,05. Apabila $r$ hitung $>r$ tabel item pernyataan valid. Kemudian apabila $r$ hitung $<\mathrm{r}$ tabel item pernyataan tidak valid.

Tabel 5. Hasil Uji Validitas

\begin{tabular}{lccc}
\hline Variabel & Indikator & Nilai rhitung & Penjelasan \\
\hline Social media & X.11 & 1.000 & Valid \\
X.12 & 0.654 & Valid \\
X.13 & 0.666 & Valid \\
X.14 & 0.558 & Valid \\
X.15 & 0.628 & Valid \\
X.16 & 0.654 & Valid \\
X.17 & 0.653 & Valid \\
& X.18 & 0.651 & Valid \\
\hline Event Marketing & X.21 & 0.638 & Valid \\
& X.22 & 0.574 & Valid \\
M.23 & 0.537 & Valid \\
\hline Y.1 & 0.594 & Valid \\
& Y.2 & 0.671 & Valid \\
& Y.3 & 0.638 & Valid \\
Y.4 & 0.501 & Valid \\
& Y.5 & 0.598 & Valid \\
& Y.6 & 0.488 & Valid \\
& Y.7 & 0.410 & Valid \\
& Y.8 & 0.510 & Valid \\
& Y.9 & 0.544 & Valid \\
& Y.10 & 0.538 & Valid \\
& Y.11 & 0.506 & Valid \\
Y.12 & 0.602 & Valid \\
& Y.13 & $\mathbf{0 . 5 5 7}$ & Valid \\
\hline & & &
\end{tabular}

Vol. 3, No. 2,

Oktober 2021

hal. 171-179

e-ISSN:

2686-5009

Dari hasil tabel 5 pernyataan dari masing-masing indikator social media, event marketing, dan minat beli dinyatakan valid. Karena seluruh nilai dalam tabel $r$ hitung $>0,05$ berarti pernyataan dapat dipahami responden dan dapat dilakukan penelitian selanjutnya.

Mengukur Uji Reliabilitas adalah dengan teknik Cronbach's Alpa $>0,6$ (batas standar) maka jawaban dari responden dinyatakan reliable. Apabila Cronbach's Alpa $<0,6$ sehingga respon dinyatakan tidak reliable.

Tabel 6. Hasil Reliabilitas

\begin{tabular}{cc}
\hline Cronbach's Alpha & N of Items \\
\hline 0.970 & 24 \\
\hline
\end{tabular}

Dari hasil tabel 6 diperoleh keseluruhan nilai Cronbach's alpha 0,970 > 0,6 artinya seluruh pernyataan penelitian variabel adalah reliable. Reliable disini yaitu tabel yang meyakinkan alat pengukur bisa diandalkan.

Uji Normalitas menguji adakah distribusi normal atau tidaknya model regerasi antara variabel independen dan variabel dependen dengan metode test Kolmogorov Smirnov. Apabila sig $>0,05$ dikatakan terdistribusi normal dan apabila sig $<0,05$ dikatakan tidak terdistribusi normal.

Tabel 7. Hasil Kolmogorov Smirnov

\begin{tabular}{|c|c|c|c|}
\hline & $\mathrm{X} 1$ & $\mathrm{X} 2$ & $\mathrm{Y}$ \\
\hline$\overline{\mathrm{N}}$ & 102 & 102 & 102 \\
\hline Normal Parameters ${ }^{\mathrm{a}, \mathrm{b}}$ Mean & 34.42 & 12.68 & 54.86 \\
\hline Std. Deviation & 5.305 & 1.951 & 7.923 \\
\hline Absolute & .147 & .148 & .113 \\
\hline
\end{tabular}

Nisya Firdailla

Hanni Haerani

Pengaruh

Social Media

dan Event

Marketing

terhadap

Minat Beli di

Pyukanau

\section{Official}

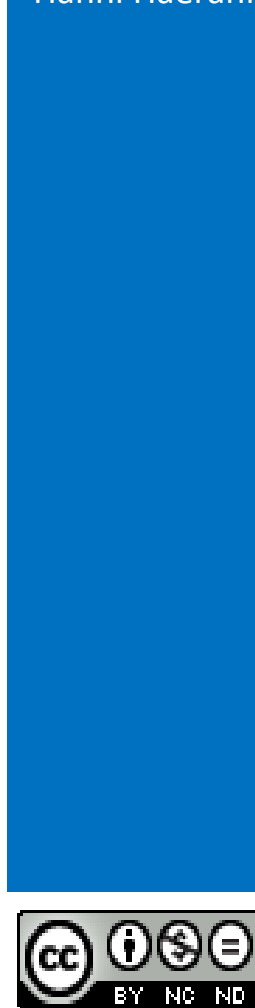


LITERATUS

adalah jurnal

yang

diterbitkan

oleh

Neolectura, diterbitkan dua

kali dalam satu

tahun.

LITERATUS

adalah media

publikasi ilmiah

dalam bentuk

makalah

konseptual dan penelitian lapangan yang terkait dengan bidang kajian sosial dan budaya.

Diharapkan LITERATUS dapat menjadi media bagi akademisi dan peneliti untuk menerbitkan karya ilmiah mereka dan menjadi sumber referensi untuk pengembangan ilmu pengetahuan.

Fokus

Sosial dan Budaya

Ruang lingkup: Humaniora Pendidikan, Manajemen, Sejarah, Ekonomi, Linguistik Sastra, Agama, Politik, Sosiologi, Antropologi, dan lainnya.

\begin{tabular}{|c|c|c|c|c|}
\hline \multirow{2}{*}{$\begin{array}{l}\text { Most Extreme } \\
\text { Differences }\end{array}$} & Positive & .147 & .126 & .100 \\
\hline & Negative & -.125 & .148 & -.113 \\
\hline \multicolumn{2}{|l|}{ Test Statistic } & .147 & .148 & .113 \\
\hline \multicolumn{2}{|c|}{ Asymp. Sig. (2-tailed) } & $.000^{\mathrm{c}}$ & $.000^{\mathrm{c}}$ & $.003^{\mathrm{c}}$ \\
\hline
\end{tabular}

Dari hasil yang diperoleh tabel 7 adalah $\mathrm{X} 1=0.147, \mathrm{X} 2=0.148$, dan $\mathrm{Y}=0.113$ di mana seluruh nilai variabel social media (X1), event marketing (X2) dan minat beli (Y) menunjukkan hasil > 0,05 sehingga dinyatakan distribusi data normal.

Tabel 8. Hasil Uji Multikolinearitas

\begin{tabular}{lcc}
\hline & Tolerance & VIF \\
\hline Social media $(\mathrm{X} 1)$ & 0.336 & 2.978 \\
Event marketing $(\mathrm{X} 2)$ & 0.336 & 2.978 \\
\hline
\end{tabular}

Dari hasil yang diperoleh pada tabel 8 nilai pada kolom tolerance menujukan nilai $>0,10$ dan kolom VIF menunjukkan angka 2,978 < 10 maka keseluruhan data dinyatakan bebas dari gejala multikolinearitas.

Tabel 9. Hasil Uji Heteroskedasitas

\begin{tabular}{lll}
\hline & $\mathrm{T}$ & Sig \\
\hline & 2.951 & 0.004 \\
Social media $(\mathrm{X} 1)$ & 4.697 & 0.000 \\
Event marketing $(\mathrm{X} 2)$ & 5.824 & 0.000 \\
\hline
\end{tabular}

Uji Heteroskedastisitas dapat diketahui dengan nilai sig $<0,05$. Nilai pada kolom sig menunjukkan, $<0,05$ maka tidak terjadi gangguan heteroskedastisitas.

Tabel 10. Hasil Uji Analisis Linear Berganda

\begin{tabular}{lccc}
\hline & $\mathrm{B}$ & Std. Error & Beta \\
\hline & 8.069 & 2.734 & \\
Social media (X1) & 0.606 & 0.129 & 0.406 \\
Event marketing (X2) & 2.045 & 0.351 & 0.503 \\
\hline
\end{tabular}

Dari hasil tabel 10 diketahui $\mathrm{Y}=8.069+0.406 \mathrm{X} 1+0.503 \mathrm{X} 2$. Konstanta $(\beta 0)=8,069$ minat beli (Y) tidak terpengaruh social media $(\mathrm{X} 1)$, event marketing $(\mathrm{X} 2)$. Fasilitas $(\beta 1)=0,406$ artinya apabila social media (X1) mengalami kenaikan 1, maka akan menyebabkan kenaikan Minat beli 0,406 dengan asumsi nilai tetap. Realibility $(\beta 2)=0,503$ artinya apabila event marketing (X2) mengalami kenaikan 1, kemudian menyebabkan kenaikan Minat beli 0,503 dengan asumsi nilai tetap.

Tabel 11. Hasil Uji Determinan

\begin{tabular}{lccc}
\hline & R & R Square & $\begin{array}{c}\text { R Square } \\
\text { Adjusted }\end{array}$ \\
\hline MinatBeli (Y) & 0.867 & 0.752 & 0.747 \\
\hline
\end{tabular}

Dari hasil tabel 11 dapat diketahui untuk mengukur tingkat keberpengaruhan nilai $\mathrm{R}=$ 0,867 dan nilai $\mathrm{R}^{2}=0,752$ yang artinya variabel social media (X1), Event marketing (X2) memberi kontribusi terhadap Minat Beli (Y) 75,2 \%. dan sisanya 24,8\% sebab pengaruh faktor asing tidak diteliti penulis. 
Tabel 12. Hasil Uji F (Simultan)

\begin{tabular}{lccccc}
\hline & Sum of Squares & Df & Mean Square & F & Sig. \\
\hline Regression & 4765.025 & 2 & 2382.513 & 49.753 & $.000^{\mathrm{b}}$ \\
Residual & 1575.053 & 9 & 15.910 & & \\
Total & 6340.078 & 101 & & & \\
\hline
\end{tabular}

Dari tabel 12 diperoleh hasil yaitu nilai sig $<0,05=$ hipotesis diterima artinya social media, event marketing berpengaruh pada minat beli. Sig $=0,000$ maka dasar pertimbangan putusan pada uji $\mathrm{F}$ bahwa social media dan event marketing berpengaruh pada minat beli. Output SPSS 26 memberikan nilai Sig $0,000^{\mathrm{b}}(\mathrm{p}<0,05)$, maka disimpulkan hipotesa dapat diterima, social media dan event marketing mempengaruhi minat beli.

Tabel 13. Hasil Uji T (Parsial)

\begin{tabular}{lcc}
\hline & $\mathrm{t}$ & $\mathrm{Sig}$ \\
\hline & 2.951 & 0.004 \\
Social media $(\mathrm{X} 1)$ & 4.697 & 0.000 \\
Event marketing $(\mathrm{X} 2)$ & 5.824 & 0.000 \\
\hline
\end{tabular}

Dari hasil tabel 13, ditemukan hasil dari uji $\mathrm{t}$ adalah: Hasilnya diketahui social media (X1) $\mathrm{t}$ hitung 4,697 > t tabel 1,984. T hitung > t tabel jadi, Ho telah ditolak sementara Ha diterima, jadi $\mathrm{X} 1$ terhadap $\mathrm{Y}$ berpengaruh positif dan signifikan. Kemudian hasil event marketing (X2) diketahui t hitung 5,824 > t tabel 1,984. T hitung > t tabel jadi Ho telah ditolak sementara Ha diterima, jadi X2 terhadap Y berpengaruh positif dan signifikan.

\section{Pembahasan}

Variabel independen yang pertama yaitu social media pada minat beli berpengaruh positif dan signifikan. Dibuktikan dari hasil tabel 13, t hitung 4,697 > t tabel 1,984 yang menerangkan bahwa hipotesis diterima. Ini berarti menjawab pada pernyataan Hipotesis pertama $\left(\mathrm{H}_{1}\right)$ yaitu "social media berpengaruh terhadap minat beli". Artinya social media mempengaruhi minat beli karena dengan berbelanja melalui social media tentunya memudahkan pelanggan untuk berbelanja online di Pyukanau Official. Biasanya usia 20 tahun sampai kurang lebih 30 tahun sangat senang berbelanja online, karena hanya dengan review atau ulasan tentang produk yang bagus bisa untuk menarik minat beli dan menumbuhkan kepercayaan berbelanja melalui social media.

Penelitian (Ningsih \& Hidayat, 2017) menerangkan social media pada minat beli berpengaruh positif dan signifikan jika produk dihasilkan sesuai dengan yang diharapkan oleh perusahaan ataupun konsumen. Semakin bagus kualitas produk akan memunculkan ketertarikan membeli ulang produk kembali. Namun penelitian ini tidak searah dengan penelitian (Astutik, 2018) yaitu apabila semakin banyak pengguna yang menyebarkan produk kosmetik melalui social media maka akan semakin banyak juga minat beli konsumennya. Meskipun dalam penelitiannya mayoritas konsumennya dari usia 25 sampai dengan usia 55 tahun jarang melakukan pembelian kosmetik lewat social media.

Variabel independen kedua yaitu event marketing terhadap minat beli berpengaruh positif dan signifikan. Dibuktikan dari tabel $13 \mathrm{t}$ hitung 5,824 > t tabel 1,984 yang menerangkan bahwa hipotesis diterima. Ini berarti menjawab pernyataan pada Hipotesis kedua $\left(\mathrm{H}_{2}\right)$ yaitu "event marketing berpengaruh pada minat beli. Artinya event yang di adakan seperti launching produk atau event-event yang selalu diikuti Pyukanau Official seperti salah satunya fashion show di acara besar, ini dilakukan di suatu tempat yang telah dipersiapkan sedemikian rupa kenyamanan dan keamanannya. Serta memberikan akses kepada siapa pun pengunjung yang akan mengikuti event setelah melakukan registrasi terlebih dahulu. Hal ini memberikan kesan terhadap brand awareness serta akan muncul ketertarikan minat membeli di Pyukanau Official.

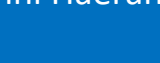


Penelitian yang dilakukan oleh (Nur, aeni \& saputri, 2021) menerangkan event marketing terhadap minat beli terdapat pengaruh yang signifikan. Karena target dilaksanakan event marketing adalah untuk menumbuhkan minat beli. Event marketing juga berpengaruh baik serta memberikan tempat yang sesuai dengan event yang berlangsung sehingga menumbuhkan minat beli konsumen (Putra et al., 2019). Namun penelitian ini tidak searah dengan penelitian (Ningrum \& Nilowardono, 2016) yang menyatakan event tidak memiliki pengaruh yang signifikan pada minat beli karena pelaksanaan event-nya memiliki beberapa faktor penghambat seperti event yang dilakukan di outdoor bisa saja hujan deras yang tiba-tiba datang membuat pengunjung tidak dapat mengikuti event tersebut. Dan event ini juga dibatasi usianya yaitu 18+ (usia 18 tahun ke atas).

\section{PENUTUP}

Social media dan event marketing telah menjadi pengaruh untuk menarik minat beli pelanggan. Berdasarkan penelitian dapat disimpulkan secara bersamaan antara social media (X1), Event marketing (X2), berpengaruh terhadap Minat Beli (Y) sebanyak 75,2\%, dan sisanya 24,8 $\%$ sebab pengaruh faktor asing tidak diteliti penulis. Event marketing tidak akan berhasil apabila tidak di publikasikan oleh media. Memanfaatkan social media untuk menyebarkan berita acara membuat event marketing dapat berjalan lancar sebab karakteristik social media yang universal dan mudah dimanfaatkan oleh seluruh kalangan. Jadi dengan adanya social media yang menjadi media alat promosi, dan adanya event marketing sebagai kunci pengenalan produk bertujuan mengenalkan industri kreatif anak bangsa untuk menarik minat beli masyarakat.

Melihat hasil penelitian, owner dari Pyukanau Official diharapkan mampu meningkatkan kreativitas di mana dalam pemasarannya melalui social media sudah baik, tapi mesti menghadirkan lebih banyak konten yang menarik serta bermanfaat seperti mengadakan giveaway, games, share tentang outfit of the day (ootd) dan konten lainnya agar tidak membosankan. Mempertahankan Event Marketing seperti saat launching produk, workshop dalam menarik minat beli. Serta memperluas jalinan perusahaan, sponsor dan pelanggan apabila dilaksanakan dengan baik. Dan bagi peneliti lainnya sebisa mungkin memakai teknik dan strategi yang lain. Supaya hasil yang didapatkan lebih bervariasi dan akurat seperti yang dituju oleh peneliti.

\section{DAFTAR PUSTAKA}

Anggraeni, R. D., Pangestuti, E., \& Devita, L. D. R. (2018). Pengaruh Endorsement Beuty Vloger terhadap Minat beli Make Up Brand Lokal (Survey pada Peminat Kosmetik LT Pro yang Dipengaruhi oleh Video Vlog Ini Vindy di Kota Malang )Jurnal Administrasi Bisnis. Jurnal Administrasi Bisnis, 60(1), 155-162. http://www.indonesiaeconomicforum.com

Fokus:

Sosial dan

Budaya

Ruang lingkup: Humaniora, Pendidikan, Manajemen, Sejarah, Ekonomi, Linguistik, Sastra, Agama, Politik, Sosiologi, Antropologi, dan lainnya.

Anugerah, D. T., \& Hidayat, A. M. (2018). Implementasi Event Marketing Dan Social Media Marketing Terhadap Keputusan Pembelian Pada PT . Niion Indonesia Utama Tahun 2018. 4(2), 305-312.

Astutik, Y. (2018). Pengaruh Media sosial terhadap Minat Beli Konsumen Wardah Kosmetik di Surabaya dengan Mediasi Sikap Merek.

Bakti, U., Hairudin, \& Alie, M. S. (2020). Pengaruh Kualitas Pelayanan, Produk dan Harga Terhadap Minat Beli Pada Toko Online Lazada di Bandar Lampung. Jurnal Ekonomi, 22(1), 101-118. https://mediakonsumen.com/2018/05/14/sur

Bellido-Pérez, E. (2019). El consumo político de moda: Buycott y slow fashion en Instagram. ZER Revista de Estudios de Comunicación, 24(46), 229-251. https://doi.org/10.1387/zer.20551

Dahmiri. (2020). Pengaruh Sosial Media Marketing dan Brand Equity terhadap Minat Beli. Kinerja, 17(2), 194-201.

Gunawan, A. (2016). Penggunaan Local Branding Dan Foreign Branding Pada Nama Produk.

Indika, D. R., \& Jovita, C. (2017). Media Sosial Instagram Sebagai Sarana Promosi Untuk Meningkatkan Minat Beli Konsumen. Jurnal Bisnis Terapan, 1(01), 25-32. https://doi.org/10.24123/jbt.v1i01.296

Irna, C., \& Tafeni, V. (2020). Analisis Event Marketing dan keputusan pembelian produk fashion lokal di kalangan pengunjung KICKEST Bandung. 6(2), 97-117. 
Ishak, R. F., \& Somadi. (2019). Analisis Efisiensi Industri Kreatif Unggulan Kota Bandung Dengan Pendekatan Data Envelopment Analysis. Competitive, 14(1), 1-13. https://doi.org/10.36618/competitive.v14i1.503

Kuspriyono, T., \& Nurelasari, E. (2018). Pengaruh Social Media Marketing Terhadap Customer Bonding dan Purchase to Intention. 18(2).

Meitasari, V. T., \& Setiawati, C. I. (2020). Pengaruh Event Marketing Teerhadap Keputusan Pembelian Produk Fashion Lokal Dikalangan Pengunjung Kickfest Bandung Tahun 2019. $7(2), 3745-3755$.

Munaf, T. (2019). Infografis Sebaran Pelaku Ekonomi Kreatif.

Neneng Nurmalasari, \& Masitoh, I. (2020). Manajemen Strategi Pemasaran Pendidikan Berbasis Media Sosial. Jurnal.Unigal.Ac.Id, volume 4(3), 543.

Ningrum, I. T. J., \& Nilowardono, S. (2016). Pengaruh Event Dan Brand Image Terhadap Minat Beli Produk Rokok Sampoerna A Mild Pada PT HM Sampoerna. 2, 57-69.

Ningsih, D. N., \& Hidayat, C. W. (2017). Pengaruh Strategi Promosi Dan Social Media Terhadap Minat Beli. Journal Riset Mahasiswa Manajemen, 6(1), 1-6.

Nur, aeni, W., \& saputri, M. E. (2021). Pengaruh Event marketing Terhadap Minat Beli Minuman Isotonik (Studi Pocari Sweat Run bandung). 8(1), 266-274.

Pramesti, A. (2018). Proses Pembetukan modal Sosial Pasar Industri Kreatif Lokal di Kota Bandung. 3(2).

Putra, R. A., Priansa, D. J., \& Pd, S. (2019). Pengaruh Event Marketing Terhadap Minat Beli Motor Kawasaki Ninja 250 Di Bandung Pada Tahun 2019. ISSN : 2442-5826 e-Proceeding of Applied Science, 5(2), 697-702.

Ratnawati, P., \& Hanifa, F. H. (2019). Pengaruh Event Marketing Terhadap Minat Beli Mobil Daithasu All New Terios ( Studi Masyarakat di Kota Bandung Tahun 2019 ). 5(2), 689-696.

Setiawati, M. (2015). Pengaruh Media Sosial Terhadap Minat Beli Konsumen. Sistem Informasi Akuntansi, 13.

Sugianto Putri, C. (2016). Pengaruh Media Sosial Terhadap Keputusan Pembelian Konsumen Cherie Melalui Minat Beli. PERFORMA: Jurnal Manajemen Dan Start-Up Bisnis, 1(5), 594.

Sugiyono. (2013). Metode Penelitian Kuantitatif Kualitatif Dan $R \& D$.

Syafiq, M. H. (2017). Penerapan Event Marketing Terhadap Pengunjung Dalam Upaya Memperatahankan Citra Merek (Brand Image) Solo Paragon Lifestyle Mall. 